\title{
Factors Affecting the Employees’ Turnover at the Ministry of High Education in Gaza Governorates - Case study: North and West Gaza Directorates of Education
}

\author{
Wasim I Al-Habil*, Abed Allah and Momhammed Shehadah
}

Masters Degree in Business Administration, College of Commerce, Islamic University of Gaza, Israel

\begin{abstract}
This study aims at identifying the factors which influence the turnover phenomenon of the Employees of the Ministry of Education and Higher Education in the Gaza Strip. The Ministry of Education in Gaza suffers from the employee turnover phenomenon. Statistics show that the number of employees who have quit their jobs at the Ministry since 2010 is 829 administrative staff and teachers. This requires the attraction of new employees to fill the vacancies. The study population included all of the previous employees, including teachers, who have worked at North and West Gaza Governorates and willingly quit since 2010. To achieve the study objectives, the researcher gathered the data from different sources. The descriptive analytical approach was adopted through using a stratified random sample of the research population. The study sample consisted of previous teachers who worked at public schools and administrative staff and professionals who worked at the North and West Gaza governorates. The total number of sample individuals was 307; then 260 questionnaires were distributed and 239 were retrieved. SPSS Program was used for the data analysis. The results show that all work-related factors (payments, job performance, role clarity, job satisfaction, and organizational commitment) influence the employees' turnover. As for external factors (employment perception and unions' presence), the results show that employees' turnover is affected by the employment perception, but not affected by the presence of a union. The Multiple Correlation Coefficient $\mathrm{R}=0.776$ and R-Square $=0.589$. This means that $58.9 \%$ of the variation in Turnover is explained by all independent variables together. The study recommends decision makers at the Ministry of Education to search for the connection between employees' turnover and turnover intentions. In addition, it should make use of the data it collects about the turnover intentions to identify and target valuable employees with high turnover intentions. The employees' job satisfaction should be evaluated and reinforced, and meetings should be held with quitters to understand the factors which led to their resignation. To limit employees' turnover phenomenon, the Ministry should work on achieving better level of organizational commitment.
\end{abstract}

Keywords: Social; Organizational; Correlation; Management

\section{Introduction}

All governmental and private organizations are trying to implement the optimal utilization of their resources, whether human or financial resources or raw materials to achieve their goals and objectives. The human resources are of the most important of these resources because an organization can organize and control the exploitation of the rest of the organization's resources appropriately through human resource management. The basis of the progress and development in various fields of life is the organization's ability to explore the elements of the human performance in terms of efficiency and productivity, which leads to developing the overall effectiveness of the organization. Employee's turnover is a much studied phenomenon. However, there is no standard account for why people choose to leave an organization. This is noteworthy because it is typically the occasions where people choose to leave that concern organizations and organizational theorists [1]. Employee turnover refers to the termination of an official and psychological contract between an employee and an organization. There are two major types of employee turnover: involuntary and voluntary [2]. Involuntary turnover is initiated by the organization to terminate the relationship with an employee, whereas voluntary turnover is primarily initiated by the employees themselves [3]. In the academic literature, turnover intention is commonly used as a measure of anticipated workplace turnover. Intent to leave, intent to quit, intention to leave and turnover intention are often used interchangeably. Voluntary turnover incurs significant cost, both in terms of direct costs (replacement, recruitment and selection, temporary staff, management time), and also (and perhaps more significantly) in terms of indirect costs (morale, pressure on remaining staff, costs of learning, product/service quality, organizational memory) and the loss of social capita [4]. The issue of voluntary turnover has been rigorously studied over the past few decades. Empirical evidence indicates that a high rate of voluntary turnover is costly for organizations because it negatively affects organizational effectiveness and success [5]. Losing good employees can negatively affect an organization's competitive advantage; lowering the morale of other staff [6], as well as reducing productivity and work quality [7]. Despite these unfavourable consequences, the voluntary turnover rate across the globe remains relatively high. Previous research suggests that high work engagement leads to lower voluntary turnover. Highly engaged employees exhibit higher quality behaviours and performance. The evidence suggests that having engaged employees results in greater profitability, shareholder returns, productivity and customer satisfaction. Employees are an

*Corresponding author: Wasim I Al-Habil, Department of Business Administration, College of Commerce, Islamic University of Gaza, Israel, Tel +970 8 2644400; E-mail: walhabil@iugaza.edu.ps

Received October 13, 2017; Accepted October 19, 2017; Published October 28 , 2017

Citation: Al-Habil WI, Allah A, Shehadah M (2017) Factors Affecting the Employees' Turnover at the Ministry of High Education in Gaza GovernoratesCase study: North and West Gaza Directorates of Education. Arts Social Sci J 8 : 304. doi: 10.4172/2151-6200.1000304

Copyright: @ 2017 Al-Habil WI, et al. This is an open-access article distributed under the terms of the Creative Commons Attribution License, which permits unrestricted use, distribution, and reproduction in any medium, provided the original author and source are credited. 
organization's crucial source of consistent competitive advantage. Therefore, organizations are required to create and maintain longterm relationships with this resource and to ensure greater share in the market. According to Abbasi and Hollman [8], the hidden and visible costs of turnover in Pakistan organizations equalled somewhat $\$ 11$ billion annually, besides the low-level employee morale for the ones who choose, some way or the other, to remain with the organization. Therefore, an organization can contribute significantly to its human resource career development by supporting career development activities within the organization. Harter et al. [9] believe in positive association between development and retention. Similarly, skill acquisition, career advancement, performance recognition, and opportunity are acceptable exchanges for retention and commitment. All these underscore the need for validation of the theory in different cultures and organizations. This thesis aims at identifying the factors which influence the turnover phenomenon of the Employees of the Ministry of Education and Higher Education in the Gaza Strip. The Ministry of Education in Gaza suffers from the employee turnover phenomenon. This study displays three factors affecting the Employee Turnover: external (Employment perception and Union presence), work-related (Payment, Job performance, Role clarity, Overall job satisfaction, Organizational commitment), and personal factors.

\section{Research Problem}

The Ministry of High Education was established soon after the Palestinian National Authority had held responsibility for managing the education sector in Palestine in 1994. Two years later (1996), a new Ministry was established for the Higher Education and Scientific Research. However, the two ministries were re-integrated in one entity based on a ministerial reshuffle for the Palestinian government in 2002, with the name "the Ministry of Education and Higher Education" [10]. This research examines the case of employee turnover among the employees of the Ministry of High Education in Gaza (MOHE). Specifically, there is an increasing number of teachers leaving the schools of the Ministry of High Education to the schools of the United Nations Relief and Work Agency (UNRWA). Reports show that (829) fix-term appointed administrative staff and teachers have left the Ministry of High Education since 2010, 610 teachers who left the schools of Ministry of High Education and moved to UNRWA schools. The turnover rate in $\mathrm{MOHE}=5.7 \%$ as shown on page 10 . According to many books in HR, all of them they state that the acceptance norm of the turnover is $5 \%$ or below, if it reached more than $5 \%$ then there is a problematic issue. This percentage is high if compared to the turnover rate in the Ministry of Health (the second largest civil ministry in terms of number of employees in the Gaza Strip after the MOHE), which is reported $1.7 \%[11,12]$. This shows the importance of studying this phenomenon and identifying the influencing factors and drawing conclusions and guidance to reduce this phenomenon. In addition, (53) short-term teachers have moved to UNRWA schools during the educational year 2015/2016. This, in turn, means that the MOHE in Gaza is required to recruit and appoint new teachers to fill the gap. This is an issue to the Human Resource Management which will cost the MOHE time, efforts and money to recover the lost human resources, and the lost educational staff after having been trained and having acquired the technical skills. In addition, the loss of such staff negatively impacts the educational process and causes disruptions throughout the scholastic year. This problem forces the MOHE to appoint sometimes unqualified teachers through short-term contracts to fill the gaps, especially during the scholastic year. The research problem could be identified as
"What are the factors that affect the Ministry of High Education employees' turnover in Gaza?"

\section{Research Variables}

The researcher reviewed the related literature where the chosen factors, which affect Employee Turnover, were studied by Dubey et al. [13]. This model is applied to explore the personal reasons affecting Employee Turnover at humanitarian organizations. Through a metaanalytic (Meta-analysis is a label for a variety of procedures that statistically summarize the information gathered in a literature review) review of organizational literature, Cotton and Tuttle identified 24 variables that affect Employee Turnover, and classified them into three correlates (i.e., external, work-related and personal characteristics). This model is a comprehensive model because it includes most of the variables which were used to investigate and discover the factors that affect Employee Turnover at any organization. This research will apply this model after some modification. The number of factors was reduced to make this study more realistic and applicable.

\section{Independent variables}

Independent variables are the factors that affect the employees' turnover phenomenon at the Ministry of High Education in Gaza, which are:

\section{1) External factors: include two variables}

a) Employment perception.

b) Union presence.

2) Work-related factors: include five variables

a) Payment

b) Job performance

c) Role clarity

d) Overall job satisfaction

e) Organizational commitment.

3) Personal actors: include four variables

a) Age

b) Gender

c) Years of Experience

d) Number of dependents.

\section{Dependent variable}

The employees' turnover phenomenon at the Ministry of High Education in Gaza (Figure 1). Developed by the researcher based on Dubey et al. [13].

\section{Research Hypotheses}

This research answers its main question through testing the following hypotheses:

1. There is a significant statistical correlation at $(\alpha \leq 0.05)$ level between the external and work related factors and the employees' turnover phenomenon at the Ministry of High Education in Gaza.

Derived Sub-Hypotheses:

a) There is a significant statistical correlation at $(\alpha \leq 0.05)$ level 


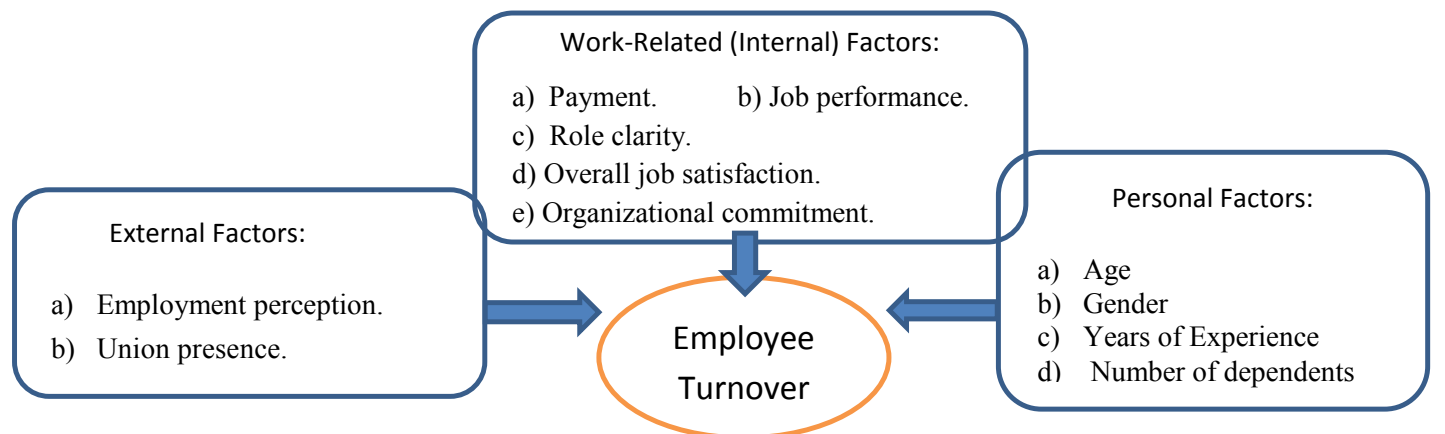

Source: Developed by the researcher based on Dubey et al. [12].

Figure 1: Research model.

between the external factor: 'the employment perception' factor and the employees' turnover phenomenon at the Ministry of High Education in Gaza.

b) There is a significant statistical correlation at $(\alpha \leq 0.05)$ level between the external factor: 'the union presence' factor and the employees' turnover phenomenon at the Ministry of High Education in Gaza.

c) There is a significant statistical correlation at $(\alpha \leq 0.05)$ level between the work-related factor: 'the payment' factor and the employees' turnover phenomenon at the Ministry of High Education in Gaza.

d) There is a significant statistical correlation at $(\alpha \leq 0.05)$ level between the work-related factor: 'the job performance' factor and the employees' turnover phenomenon at the Ministry of High Education in Gaza.

e) There is a significant statistical correlation at $(\alpha \leq 0.05)$ level between the work-related factor: 'the role clarity' factor and the employees' turnover phenomenon at the Ministry of High Education in Gaza.

f) There is a significant statistical correlation at $(\alpha \leq 0.05)$ level between the work-related factor: 'the overall job satisfaction' factor and the employees' turnover phenomenon at the Ministry of High Education in Gaza.

g) There is a significant statistical correlation at $(\alpha \leq 0.05)$ level between the work-related factor: ' the organizational commitment' factor and the employees' turnover phenomenon at the Ministry of High Education in Gaza.

2) There is a statistically significant effect at $(\alpha \leq 0.05)$ level for the external factors (employment perception and union presence) and work-related factors (payment, job performance, role clarity, job satisfaction and organizational commitment) on the turnover phenomenon.

3) There are statistically significant differences at $(\alpha \leq 0.05)$ level among the respondents in their opinions about the factors that affect employees' turnover at the Ministry of High Education in Gaza attributed to their characteristics factors (such as gender, age, number of dependents and experience).

\section{Research Importance}

This study is important for both:

\section{The MOHE:}

- The utilization of the study conclusions and recommendations can help the MOHE in the identification of the priorities and recognition of the gaps between the real situation and the prospects in the field of employees' turnover at MOHE

- The study can help decision makers at MOHE in the minimization of the negative results of this issue and help them find the appropriate solutions.

- The study can raise the awareness of policy makers, educational planners, teachers, school administrators and other concerned bodies.

2. The Islamic University of Gaza and other researchers:

- This study is considered the first to study the factors affecting the phenomenon of employees' turnover at the Ministry of High Education in Gaza.

- This research will contribute to the enrichment of the researchers' knowledge regarding the concept of turnover through their review of previous studies, articles and books related to the research topic, which will also improve their researching skills.

\section{Research Limitations}

a) The following limitations were identified by the researcher while conducting the field work

b) The study has been taken in public sector, it may not be applicable to other sectors or industries

c) One of the main challenges in data gathering process was getting former employees. Some employees left abroad and those communicated over the internet were challenged to get their exact address.

d) Few respondents were not able to return a questionnaire in due time and it was a difficult task to wait until all return as intended. Hence, these limitations have a negative impact on the quality of the subject study.

\section{The Concept of Turnover}

As the world advances, so do certain concepts. The present-day world embraces a new instrument 'Employee Turnover' that allows employers to test the management effectiveness at an organization. People in charge should take into consideration such tool and make 
use of the results it shows while working on the design of human resources plans and while foreseeing the insufficiency of employees. Scholars have been conducting plenty of studies on employees' turnover [13]. Multiple researchers and scholars have given 'Turnover' different definitions. As a concept, it could mean the circulation of staff members, whether inside or outside an organization [14]. Commonly used, 'Employee Turnover' describes employees who move from the place they work for to a different one $[15,16]$. In addition, this term includes the employment and recruitment of new staff. The studies conducted in this regard concentrate on employees who leave organizations, instead of those who are hired. Khan [17] defines Turnover as the reverse position of an employee in an organization. Lots of scholars, though, have defined 'Turnover' in a simple way; to Tett and Meyer [18], Turnover is when employees consciously want to search for other possible organizations. It is also defined as "the cessation of membership in an organization by an individual who received monetary compensation from the organization [19]. This study looks into the turnovers of teachers and managerial employees. This study reviews this topic from researchers' point of view. Teacher Turnover is similar to Employee Turnover at organizations; it occurs when teachers quit their jobs. Including multiple meanings, Turnover generally describes "the departure of teachers from their teaching jobs".

\section{Turnover types}

Turnover can be classified into two principal categories; permanently leaving an organization: A. voluntarily, B. involuntarily. Voluntarily leaving an organization, i.e., Voluntary Turnover, means that staff members themselves decide to stop working at a certain organization. Here, the first step is taken by the employees; they choose to end the work relation they have with their workplace, or employers. In this case, staff members take the decision of leaving a certain workplace for private or work-related reasons. Assefa [15] says that opposite to it is "Involuntary Turnover". The first step, here, is taken by the authority itself (i.e. the employer or organization). Involuntary Turnover means that the staff member does not have a say in it. Members can involuntarily leave their jobs for having died or suffered an illness. In addition, Involuntary Turnover can be initiated by employers because of the lack of staff members' proficiency, or because the organization has taken in a new way of work such as reengineering, or has decided to downsize its workers; resulting in a fewer number of workers. Bennell [20] says that there are two possible Turnovers, one that happens voluntarily and one that occurs involuntarily. The first is usually because the employees decided to quit, or retire early; as for the second it occurs because of death, sickness, discharge, or old age (time for retirement). Furthermore, there are other studies that have classified Voluntarily Turnovers into two categories; one that is "functional" (beneficial), and the other being "dysfunctional" (costly). According to Stovel and Bontis [21], Dysfunctional Turnover can be classified into two types: one that is avoidable, and the other that is unavoidable. First, organizations can sometimes prevent the occurrence of 'Dysfunctional Turnover' through multiple strategies and techniques. For example, an organization can employ new capable staff, constantly assess the performance of employees, and encourage its employees. Usually this type of Turnover is the result of bad wages, bad working environment and other discouraging job surroundings. On the other hand, sometimes 'Dysfunctional Turnover' cannot be avoided. Plus, there are out-of-hand reasons such as having to move to a different region for family reasons, severe sicknesses, death... etc. In such cases, there is nothing an organization can do.

\section{Consequences and Effects of Turnover}

In any workplace, there are those excellent employees who help make an organization better. Those assets usually tend to leave and change their workplace. If such turnovers occur greatly at an organization, the results could be very negative. When the brilliant ones are those who leave, the organization could suffer from lack of productivity that customers do not get quickly served, and if the organization tries to introduce programs, there will be no good-enough employees to apply. Therefore, an organization could lose the path it has set to achieve its original objectives [21]. Governmental posts are no different from organizations. Whenever an asset employee leaves, the possibility for having bad effects increases. What happens is that the services become less than expected, affecting the citizens' approval of the services they receive [22]. In public posts, it is only fair to say that there are two types of customers: First, the actual clients who go to receive certain government-related services; second, the actual employees. HR Department at a governmental workplace should provide the employees with what they need so to ensure they stay in office for long, and to reduce turnovers. Employees who are well-served at their workplaces will always be able to provide equally great services to the citizens, clients. Any work environment is a representation of the society we live in. Therefore, the web that connects the employees at an organization is created after the employees communicate and establish a channel of understanding between them. When turnovers occur, such connection is broken, affecting the organization financially and socially - considering the employees a family [23]. Tempting employees to stay is important to keep them and reduce turnovers. All employees want to feel secured about their future and want some privileges. Since the future of an organization and its success are bound to its excellent staff members, an organization should meet the needs of its employees. Generally, for an organization to ensure having high-quality services, it should keep its excellent employees who have long experience in the job post they fill [24-26]. Schools suffer from "Teachers Turnover". When great teachers quit their job or go to different schools, the consequences are negative to both schools and students. A. Students have lost wonderful teachers, so they do not get to experience the joy of having amazing teachers. B. Schools will have to find new teachers, and will have to train them. Ingersoll found in a study he conducted in the USA that one of every two new teacher leaves classroom by the end of five years of teaching.

\section{Measuring Staffs Turnover}

According to Swarnalatha [27] for the calculation of "Employee Turnover, one needs to divide $\mathrm{x}$ from $\mathrm{y}$; $\mathrm{X}$ representing the number of staff members who left an organization, and Y representing the base number of jobs while being there. Retirement, phasing out and downsizing-based termination are excluded from this calculation, which takes place over 12 months (a year).

To calculate the Turnover rate, one needs the following index:

Total turnover rate $=[\mathrm{NS} / \mathrm{AN}] \times 100$

NS=number of employees separated in the period

$\mathrm{AN}=$ average number of employees in the unit in the period

Turnover rate at the MOHE in the period (2010-2016)=NS=829

$\mathrm{AN}=(12925+15952) / 2=14438.5($ Tables $1-3)$

Turnover rate at the MOHE $=829 / 14438.5=5.7 \%$.

As mentioned earlier, another type of Turnover is Internal, which 
could be a result of being promoted at an organization. This type, however, is not included in the equation of 'Employee Turnover'. In other workplaces, say at an organization, it is possible to include the statistics of new employees for a precise description of Turnover during a certain year [26].

Using the equation to measure the turnover rate, the Turnover equals the number of employees leaving divided by the total number of employees in certain period.

\section{Literature Review}

The Ministry of Education is considered the largest of Palestinian ministries in terms of staff numbers. Therefore, the human element is one of the key resources of this institution. In addition to the headquarters of the ministry, there are seven buildings or directorates for managing and following-up with the educational process in all governorates. Each directorate is responsible for affiliating schools in the same province, where the directorate follows-up with these schools,

\begin{tabular}{|l|c|c|c|}
\hline Directorate & Male & Female & Total \\
\hline North Gaza & 839 & 1133 & 1972 \\
\hline Khanyounis & 802 & 1144 & 1946 \\
\hline Rafah & 529 & 670 & 1199 \\
\hline Middle Area & 490 & 563 & 1053 \\
\hline East Gaza & 585 & 653 & 1238 \\
\hline East Khanyounis & 461 & 470 & 931 \\
\hline West Gaza & 758 & 885 & 1643 \\
\hline Total & 4464 & 5518 & 9982 \\
\hline
\end{tabular}

Table 1: The distribution of teachers in MOHE at 2016.

\begin{tabular}{|l|c|c|c|}
\hline \multicolumn{4}{|c|}{$\mathbf{2 0 1 0}$} \\
\hline Directorate & Male & Female & Total \\
\hline North Gaza & 1010 & 828 & 1838 \\
\hline Khanyounis & 826 & 655 & 1481 \\
\hline Rafah & 662 & 559 & 1221 \\
\hline Middle Area & 755 & 753 & 1508 \\
\hline East Gaza & 1117 & 1070 & 2187 \\
\hline East Khanyounis & 641 & 408 & 1049 \\
\hline West Gaza & 1202 & 1188 & 2390 \\
\hline Ministry Building & 1031 & 220 & 1251 \\
\hline Total & 7244 & 5681 & 12925 \\
\hline
\end{tabular}

Table 2: The distribution of all staffs at 2010

\begin{tabular}{|l|c|c|c|}
\hline \multicolumn{3}{|c|}{$\mathbf{2 0 1 6}$} \\
\hline Directorate & Male & Female & Total \\
\hline North Gaza & 1260 & 1139 & 2399 \\
\hline Khanyounis & 973 & 822 & 1795 \\
\hline Rafah & 795 & 724 & 1519 \\
\hline Middle Area & 901 & 852 & 1753 \\
\hline East Gaza & 1387 & 1440 & 2827 \\
\hline East Khanyounis & 756 & 599 & 1355 \\
\hline West Gaza & 1369 & 1423 & 2792 \\
\hline Ministry Building & 1239 & 273 & 1512 \\
\hline Total & 8680 & 7272 & 15952 \\
\hline
\end{tabular}

Table 3: The distribution all staffs at2016. supervises them and meets their needs [27,28]. The following table shows the distribution of teachers working in the MOHE. The Ministry of Education is one of the governmental institutions that suffers most from employees' turnover. One of the reasons, especially for teachers, is the existence of alternative opportunities that may be attractive; these are UNRWA schools. Generally, statistics show that there are (829) fixterm appointed administrative staff and teachers in the Ministry of High Education and (7) educational directorates who have left their jobs since 2010 (Tables 1-4), (Figures 2-4). Mesmeh et al. [29] suggested that why Nurses Leave their Work from Governmental Hospitals to Primary Health Care Centers in Gaza Governorates: This study aims at providing an understanding for the motives which drive nurses out of public hospitals to Primary Health Care (PHC) Centers in the Gaza Governorates. The researchers used a descriptive analytical approach in the study, which covered the thirteen hospitals run by the $\mathrm{MOH}$ (Ministry of Health) in the Gaza Strip. A total of 105 questionnaires were distributed, representing the entire study population. The results of this study indicated that nurses decide to quit from public hospitals and work at private centers (PHC) in the Gaza Strip for 3 principal reasons: longer working hours at hospitals, difficulty of tasks, and the democratic nature of hospitals. So for less movement of nurses from public hospitals to PHCs, the following are recommended: (A) Clarifying the tasks of the job (responsibilities and rights); (B) Teaching

\section{Administrative Staff}

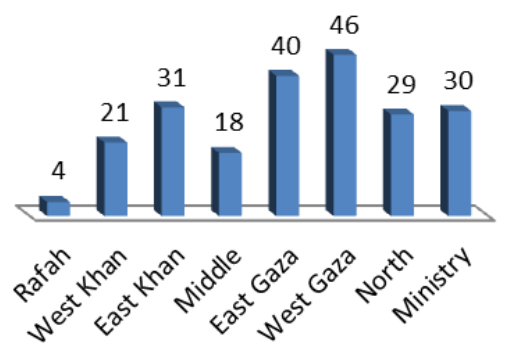

Figure 2: Administrative Staff's Turnover Statics since 2010

\section{Teachers}

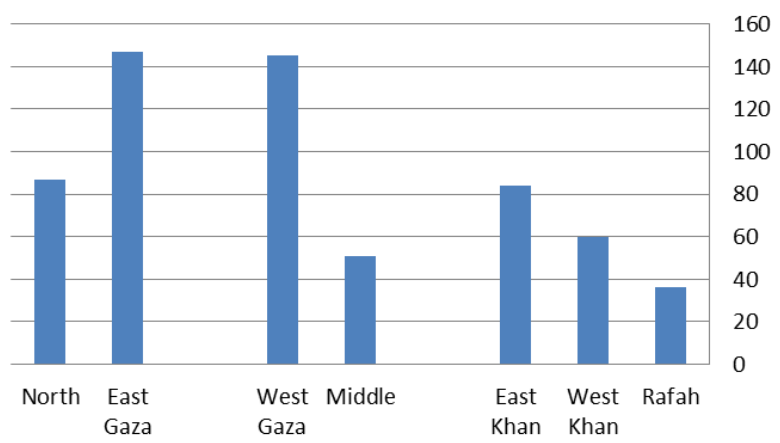

Figure 3: Teacher's Turnover Statics since 2010.

\begin{tabular}{|c|c|c|c|c|c|c|c|c|c|c|c|c|c|c|c|c|c|c|c|c|c|c|c|c|c|c|}
\hline$\%$ & Total & $\mathbf{F}$ & $\mathbf{M}$ & Rafah & $F$ & M & $\begin{array}{l}\text { West } \\
\text { khan }\end{array}$ & $F$ & $\mathbf{M}$ & $\begin{array}{c}\text { East } \\
\text { Khan }\end{array}$ & $\mathbf{F}$ & M & Middle & $F$ & $M$ & $\begin{array}{l}\text { East } \\
\text { Gaza }\end{array}$ & $F$ & M & $\begin{array}{l}\text { West } \\
\text { Gaza }\end{array}$ & $F$ & M & North & $\mathbf{F}$ & $\mathbf{M}$ & Ministry & \\
\hline 0.74 & 610 & 23 & 13 & 38 & 29 & 31 & 60 & 37 & 47 & 84 & 28 & 23 & 51 & 78 & 71 & 147 & 71 & 74 & 145 & 41 & 48 & 87 & 0 & 0 & 0 & Teachers \\
\hline 0.28 & 219 & 1 & 3 & 4 & 3 & 18 & 21 & 6 & 25 & 31 & 7 & 11 & 18 & 8 & 32 & 80 & 13 & 33 & 48 & 4 & 25 & 39 & 4 & 26 & 30 & Others \\
\hline $100 \%$ & 829 & 24 & 16 & 40 & 32 & 49 & 81 & 43 & 72 & 115 & 35 & 34 & 69 & 84 & 103 & 187 & 84 & 107 & 191 & 45 & 71 & 16 & 4 & 26 & 30 & Total \\
\hline
\end{tabular}

Table 4: The study population representation. 


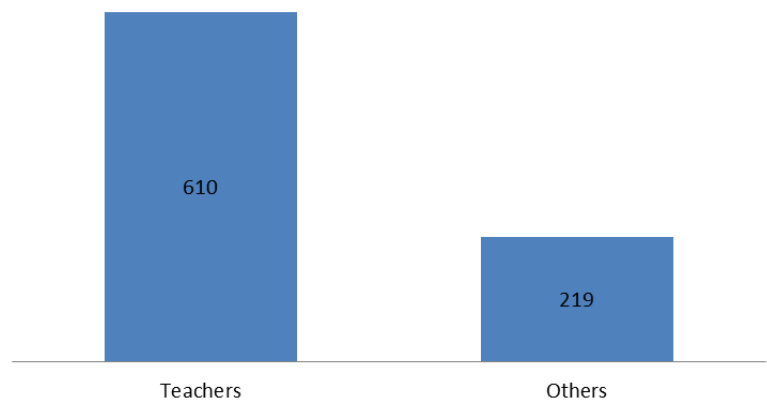

Figure 4: Teachers' and the Others Turnover since 2010.

nurse managers how to perform their jobs; (C) Enhancing the surroundings of the work (i.e. the facilities and infrastructure); (D) Offering a safer environment and better conditions for patients [28]: HR Role and Influence on the Turnover and Migration of Doctors in Hebron and Bethlehem Governorates: The purpose of this study is to see how HR affects the employment of physicians (from the second they are chosen until they are hired). In addition, it seeks to see what role HR plays in the preparation of doctors for practical work, and how money (i.e., salaries and financial rewards) affects the Turnover and resignation of doctors. This study also seeks to point out what promotions in hospitals consist of and their effects on Turnover and resignation; and what makes a doctor continue his $\backslash$ her work at a hospital or leave. Because of the requirements of this research, the researcher depended on the descriptive approach, which offers quantitative and qualitative understanding of the topic under study. As a tool, she used a questionnaire, and analyzed it using SPSS. From the actual number of questionnaires distributed, she analyzed 96 questionnaires only (the sample of the research). As for why doctors leave, the results have shown that money and privileges are key reasons. Thus, hospital managers should provide a better surrounding for work, more training courses, better payments, deeper understanding of their needs (which should be met) and more practical solutions to their issues [29]. The Impact of Organizational Factors on Nurses Turnover Intention Behavior at Public Hospitals in Jordan: How Does Leadership, Career Advancement and Pay-Level Influence the Turnover Intention Behavior among Nurses: This study aims at identifying the relationship between organizational factors (leadership, advancement opportunities, and pay level) and turnover intentions. The sample included 600 nurses working at governmental hospitals. The nurses were selected randomly; and the study tool was a survey. The study found that the turnover intentions of nurses are significantly affected by leadership and the pay level and there exists a significant relation between advancement opportunities and turnover intentions among nurses. This study recommended that it should be taken into consideration that employees could act negatively, like having turnover intentions, when they experience low leadership quality, pay level and advancement opportunities [30]. Organizational Commitment and Turnover Intentions: Impact of Employee's Training in Private Sector of Saudi Arabia: This research, conducted in Saudi Arabia, is to identify the effects of having employees trained on 2 main factors (organizational commitment and turnover intentions). It targeted the private sector in its attempt to connect between the two mentioned factors. The researchers depended on the literature of the two factors as the base for their model and hypotheses. The study tool was a questionnaire constructed by the researchers; questionnaires were sent to 251 sample individuals working at different private organizations in Saudi Arabia.
Testing the theory on the private sector only, it could be possible to say that this research's results cannot be generalized to cover different study populations or settings. It can be, though, viewed to have similar results to organizations that work in the same field and have similar characteristics. The study found that there exists a negative relationship between organizational commitment and turnover intention strongly supporting the hypothesis. This study recommended that it is highly important for organizations to train their employees on understanding the organization's goals, missions and values through training [31]. Effect of Organizational Climate on Job Turnover of Employees at Tourism Hotels in Petra Region of Jordan: The place under study is Petra in Jordan. The purpose of the study is to point out how satisfied employees at tourism hotels feel towards the general atmosphere of their work conditions. The researcher will look into certain workrelated constituents (i.e., what type of work employees do at such hotels, how the hierarchy is shaped and control is applied, and how the relationship between managers and workers is like; plus, money-related issues). Questionnaires were sent to 362 employees (the sample). The study found that the influence of work-related constituents on turnovers varies. They are arranged as follows: (1) Work environment, (2) Relationship between managers and employees, (3) Reward and punishment methods, (4) Methods followed in authority, and (5) Job security. For better performance and less turnover, employees need to feel secure and stable at their job [32]. Job Satisfaction and its Impact on Labor Turnover, the Case Study was Carried at Port Sudan Grain Silo (PSGS): The purpose behind this study is to identify which elements influence Turnover and the performances of employees. This study seeks to define the concept of Turnover and how it affects the quality of employees' performances. In addition, it aims at looking into the relation between Job Satisfaction and Turnover; it also tries to identify the importance of the feeling of satisfaction for employees in the achievement of the organizations' goals. The researcher used the descriptive analytical approach. The researcher collected both primary and secondary data: The first from interviews and questionnaires; the latter from references, online resources and annually-issued reports. The place under study is Port Sudan Grain Silo (PSGS). The study found that the relationship between turnovers and employees' satisfaction at PSGS is negative. This study recommended that workplaces should offer sufficient amount of money to employees; it should cover their needs. If so, employees would continue their work and advance towards a better future [33]. The Relationship between Quality of Work Life and Turnover Intention of Primary Health Care Nurses in Saudi Arabia: This study was conducted to point out the connection between QWL and nurses' turnover from PHC in SA. The researcher used a cross-sectional survey as the study tool. For the collection of data, the researcher used: 1) Brooks' Survey of Quality of Nursing Work Life. 2) Anticipated Turnover Scale. 3) Demographic data questions. The sample consisted of 508 Primary Health Care nurses in Jazan, SA (RR=87\%). Descriptive statistics, t-test, ANOVA, General Linear Model (GLM) univariate analysis, standard multiple regression, and hierarchical multiple regression were applied for analysis using SPSS v17 for Windows. The nurses showed tendency towards wanting to leave their jobs; i.e. from the PHC centers ( $40 \%$ of the sample's respondents). They did not feel comfortable with their work life. Such desire was greatly linked to the quality of work life. Nurses, as shown in the research results, have the desire to change their jobs because of the low quality of work life at PHCs. In order to keep them from leaving, PHCs should consider providing a better work life for the nurses through offering a better work environment. Such step would result in nurses with more commitment, and nurses who are more productive [34]. Main Factors Causing Workers Turnover in 
Jordan Industrial Sector: The purpose of this study was to identify the causes of Turnovers in the Industrial Sector of Jordan. The researcher used a questionnaire as the study tool; they were sent to more than 28 factories in Jordan. 14 of the factories were divided into two categories: those which were in the most important industrial cities, and those which were outside them. The researcher focused on 5 variables that could affect Turnovers. Those factors are related to money, the surroundings of the job, the shared interaction with the management, how the workers feel about their surroundings psychologically, and the privileges offered by mangers to workers. The study found that there are two principal reasons why Turnovers occur in the industrial sector in the country under study: the work environment, and salary. Work environments should be improved and the money offered to employees should be increased to limit turnovers [35]. Work Stress and its Impact on Working Turnover for the Workers in Border Guards Centers in Eastern Region (K.S.A): This study aims at understanding how work pressure affects turnover at Border Guards' centers. The place under study is the Eastern Region. The population of the study covers 2000 officers and privates; however, the sample was 376 individuals only. A descriptive approach was used. The data collection tool was a questionnaire. The study found that there is a statistical relation between work pressure and Turnover at three levels: (1) transferring, (2) resignation and (3) early retirement. Management should conduct annual follow-ups with turnovers which occur at the centers. Through such steps, it could detect the reasons and try to prevent them [36]. The Impact of Turnover and Availability of Employees on the Organization Performance: This study aims at identifying the influence of Turnovers and employees' availability on the organization's performances. This study concentrates on reasons behind missing work, especially those which impact the organization's daily work. The researcher here used the descriptive analytical approach. Two types of data were collected: Primary data and secondary data. The first type was collected through actual interaction with the Sudan Cotton Company (a sample was selected to test the hypothesis); the second was collected through records, books and periodicals. The study found that turnovers greatly affected the production of the Cotton company and its performance. The company should concentrate on improving the financial motivations it offers to its employees. It is recommended that its system of incentives should be performance-based [37]. The Turnover Factors among Private Schools Teachers in the Southern Region of Jordan: The aim of this study was to look into the reasons behind turnovers of teachers working at private sectors. The place under study was the southern area of Jordan. The population of the study was 1,225 male and female teachers; only 563 were selected as a sample: 133 male teachers and 410 females. The researcher used different methods such as means and standard deviations, multi-variance analysis, and one way Anova. The study found that the arithmetic means of reasons behind turnovers were moderate; while those linked to schools' administration were high. Private schools should follow up with the teachers' desires and requirements regularly, and should try to meet them in ways that benefit the schools' objectives. Understanding Employee Turnover in Humanitarian Organizations: This study aims at pointing out the causes of turnovers at humanitarian organizations. A survey was conducted on directors working at such organizations, who had access to all operations. The sample was randomly selected from the National Institute of Disaster Management (NIDM). 121 questionnaires were distributed. The study found that there were three types of factors affecting turnovers: external, work-related and personal. In the first type, employment perception's factor loading was more than 0.7. All factors linked to work-related were significant. As for the third type, personal information, marital status, number of dependents, aptitude and ability and intelligence had the highest loadings. The employees' understanding of work tasks has a great impact on turnovers. Humanitarian organizations should take this into consideration [38]. Effects of Alternative Opportunities and Compensation on Turnover Intention of Singapore PMET: The scarcity of skillful labor in Singapore obliges companies to do their best trying to attract and retain the correct personnel. The research objective was to investigate the combined effect of perceived job alternatives, salaries, and employees' satisfaction with the incentives they received on Turnover Intention. The study sample included 102 of the highly qualified IT professionals. Using correlation and multiple regressions; the researcher managed to make significant conclusions regarding the mentalities of Singapore's talented categories. The study found that the salaries affected the job satisfaction of professionals, managers, executives, and technicians; which in turn affected their turnover intentions. Perception of better job alternatives was also found to affect the turnover intention of Singapore's PMETs. This study recommended that the organizations should come up with innovative ways to enhance their talented personnel's satisfaction and decrease their turnover intentions [39]. The Causes and Effects of Employees' Turnover: The Case of Oromia Water Works.

\section{Design and supervision enterprise}

This study aims at identifying the reasons behind employees' turnovers at Oromia Water Works Design and Supervision Enterprise. The researcher used a mixed approach for a better description. The researcher collected both primary and secondary data. In addition, probability and non-probability sampling were used in the selection of the respondents. For the data collection, the researcher made use of different tools: surveying, interviewing and document reviewing. For the individuals who were going to be selected as a sample, the researcher used systematic and purpose-based samplings. 500 individuals are the population of the study; those are all workers at OWWDSE at the time of the carrying out of the study. The study found that there are different factors which affect employees' turnover at the Enterprise, which include: terms of employment, favorable government policy, external markets, lack of result-oriented promotion and motivation, working environments and conditions. This study recommended that the enterprise should offer its employees financial motivations. It should also allow employees' participation in making decisions and should accept their points of view when necessary. Organizational Commitment and Turnover Intention in Union and Non- Union Firms: The study tried to identify the presence of any discrepancy in employees' organizational commitment and turnover intentions between union and non-union firms. The study was conducted in the Midwestern USA, where surveys were sent to all registered construction firms. The retrieval rate was 10 percent as only 121 out of 1443 sent surveys were retrieved (some companies were no longer in the construction business). Of the 121 companies, 23 declared being union firms while 87 said they weren't. The investigated independent variables were personal traits, job features, relationship between the group and their leader, and the characteristics of the organization. The study revealed that employees of union firms had better organizational commitment but their intention to quit their jobs was higher. However, regression coefficients of the union variable were found to be statistically insignificant in both OC and Turnover Intention. The study found that OC and Turnover Intention were higher among employees of union firms. However, at the traditional level of significance, there was no statistically significant regression coefficient of the two variables. Organizations should work more to involve their employees in the decision making process. They should also encourage good relationships 
between the workers and their leader to decrease Turnover Intention [40]. Employee Turnover in a Local Government Department: This study examined turnover at a governmental post in Limpopo Province, South Africa. The researcher used a cross-sectional method design to collect the data. A cross-sectional mixed method design (questionnaires, interview, focus group and document analysis) was used to collect employee turnover data from the target population in a relative short period of time. Only one local government department in Limpopo Province was willing to participate in the study. This department has a staff complement of 1081 employees. The questionnaire was distributed among a sample of 60 employees. It was decided to select minimum sample size of $5 \%$ for this survey because of time and financial constraints [41,42]. Stratified sampling was used to obtain a greater degree of representation (decreasing the sampling error). Study findings showed that the turnover rate was high. Young employees, females, and certain workers showed higher tendency towards leaving their jobs. HR department should follow up with directors and stress on the need for employees' assessment so to ensure the latter are given enough feedback. A Study on an Assessment of Teachers' Turnover in Government General Secondary Schools of Addis Ababa: This study was conducted to identify the reasons behind teachers' turnover in Addis Ababa. The focus was on the teachers of Government General Secondary Schools. This study also tried to find solutions for the Turnover problems. The method used was the descriptive survey design. The sample consisted of 10 schools; 185 teachers who were still in position (random sampling); 83 former ones (available sampling); and 20 principles (availability sampling). The research tools were a questionnaire and interviews. The data analysis included frequency, percentage, mean and Rank order. The study found that the factors which force teachers out of school are arranged as follows: The arithmetic mean of insufficient salary and lack of privileges was 4.7, students' behavior was 4.46 , administration-related issues 4.27 and work environment 4 . This study recommended that the school boards and the Ministry of Education should improve the teachers' salaries, and carry out social awareness campaigns to brighten the social perception about teachers. Some rules should be set to ensure students' behaviors and attitudes. Factors of Job Turnover Intention among Employees of Private Universities in Selangor: The research was conducted to identify the factors affecting employees' turnover intention in university staff members in an attempt to identify the best solutions that may enhance their retention [43]. It investigated the influence of a number of variables (job satisfaction, justice in the organization, employees' commitment, perception of job alternatives and person-organization relationship) on Turnover Intention. The population comprised all teaching staff (including lecturers, associate professors, and professors) as well as administrative employees in four universities. The research tools were the questionnaire and the questionnaire surveys, 200 of which were distributed to the target categories. For the data analysis, SPSS (Software Package for Social Sciences) was used. Results were represented in summaries, bar charts, and central tendency measures. The study revealed that Turnover Intention, as a dependent variable, was moderately affected by all the investigated factors. Organizations should find ways to reinforce their staff's commitment through, for example, offering a discount to employees when buying shares of the company they work at. The Factors Affecting Employee Turnover in an Organization: The Case of Overseas Pakistanis Foundation: This study aimed at examining the relation between certain factors and employees' turnover; those factors are the privileges employees receive when they retire, how secured they feel about their jobs and any money-related issues. The data was collected from a sample of 100 people. Those people worked at different types of organizations in Overseas Pakistanis Foundation. The researcher used a questionnaire based on the Fifth Likert Scale. The study found that rretirement benefits, job security and financial crises significantly affect employees' turnover. There is a more positive relation between retirement benefits on employees' turnover than job security. The factors under study should be followed up with due to their significant impact on Turnover [44]. The Importance of Role Clarification in Workgroups: Effects on Perceived Role Clarity, Work Satisfaction, and Turnover Rates: This article investigated the effect of better role clarity on promoting job satisfaction and minimizing Turnover in workgroups. The sample included about 1,700 employees working at different offices of a government agency. Data were collected in 2 time periods from different sources, and were analyzed using multivariate analysis of variance and hierarchical regression analysis. The study found that in offices where employees' roles were clear, job satisfaction was significantly greater and Turnover was significantly less common. Managers should seek to clarify the roles of their employees and avoid any negative overlapping or ambiguity [45]. Factors Influencing Turnover Intention among Technical Employees in Information Technology Organization :a Case of XYZ Company: This study was conducted on the technical staff working at XYZ Company to look into Turnover causes. The sample consisted of 103 individuals. There were 7 variables: How committed an employee is to the organization, how stressed employees feel because of their jobs, the features of the work atmosphere, the possibilities of advancement in career, the financial aspect of the job, the quality of work environment and how satisfied employees feel about their jobs. SPSS (v. 16) was used in the data analysis. The study found that all factors except for job stress had a negative relation with Turnover, and all factors had a significant relation with it. Job Stress is considered the most influential factor on Turnover at the Company. Thus, it is necessary to motivate employees. For a company with satisfied employees, the company should allow its employees to express their opinions fearlessly.

\section{Research Methodology}

The research followed the analytical/descriptive approach and the statistical analysis. The data were collected from primary and secondary resources. The secondary resources include the use of books, journals, statistics and web pages. The primary data were collected by using questionnaires that were developed specifically for this research. Many of measurement tools "questionnaires" used by other researchers were adapted, translated, combined and modified to fit the purpose of this research, ending up in the development of one questionnaire distributed to 260 respondents to collect the primary data. The researcher retrieved 239 out of them. The questionnaires were also distributed electronically to persons who were difficult to reach due to their presence outside the Gaza Strip.

\section{Population and sample size}

The population of this study is all the employees of the Ministry of High Education in Gaza who left the North and West Gaza Directorates of Education including teachers since 2010. This research used the quantitative research method, and the descriptive analytical approach was adopted through using a stratified random sample of the research population. The population consists of (307) fix-term appointed administrative staff and teachers in North and West Gaza Directorates of Education who have left their jobs since 2010.

Samples size can be calculated based on the following equation of (Cochran, 1977), 

error $)^{2}$

Sample-size: $\mathrm{SS}=(\mathrm{Z} \text {-score })^{2} \times \mathrm{StdDev} \times(1-\mathrm{StdDev}) /($ margin of Adjusted Sample size: SSa=(SS)/(1+(SS-1)/population).

Where Z-score is given as 1.96 .

Std Dev is Standard Deviation of the worst case, taken as $50 \%$. as $5 \%$

Margin of error is the error interval and the researcher will take it

Substituting population as 307 in the above equation, sample is calculated as follows,

Sample-size $=(1.96)^{2} \times 0.5 \times(1-0.5) /(0.05)^{2}=384$.

Adjusted Sample size $=384 /[1+(384-1) / 307]=171$.

Thus, the appropriate sample size in this case is at least 171. The questionnaire was designed and distributed to the (260) MOHE employees after taking official permissions.

\section{Questionnaire Design and Procedures}

A survey questionnaire was designed to collect the research's primary data. The questionnaire included close-ended questions to facilitate the data collection process. The design of questionnaire affected the response rate and the reliability and validity of the data collected. Response rates, validity and reliability are maximized by careful design of individual questions, clear layout of the questionnaire form, clear explanation of the purpose of the questionnaire and pilot testing. By using questionnaire, large amounts of information can be collected from a large number of people in a short period of time and in a relatively cost effective way. The questionnaire consists of two sections to accomplish the aim of the research. 1-Section (1): The first section aimed at colleting the personal information of the sample including gender, age, marital status, years of experience, qualification and job grade. 2-Section (2): The second section consists of eight parts; Employment perception with 8 statements, Union presence with 7 statements, Payment with 7 statements, Job Performance with 8 statements, Role Clarity with 7 statements, Overall Job Satisfaction with 8 statements, Organizational Commitment with 8 statements and Turnover with 15 statements. The statements were arranged in an easy and logic way to be understood and responded correctly. The questionnaire was translated into Arabic language and distributed to the entire sample to enable the employees respond without difficulty.

\section{Research Measurement}

In order to be able to select the appropriate method of analysis, the level of measurement must be understood. For each type of measurement, there is/are an appropriate method/s that can be applied and not others. In this research, scale 1-10 is used. When the participant chooses a number nearer to 1 , this implies disagreement, while choosing a number nearer to 10 implies agreement.

\section{Content validity of the questionnaire}

The content validity of the questionnaire was conducted through the supervisor's review in order to assure that the content of the questionnaire is consistent with the research objectives, and evaluate whether the questions reflect the research problem or not. Also, academics from the Islamic University of Gaza and Al Azhar University reviewed the questionnaire and provided valuable notes to improve its validity that their comments were taken into consideration.

\section{Pilot Study}

A pilot study of 30 respondents for the questionnaire was conducted before collecting the results of the sample. It provided a trial run for the questionnaire, which involves testing the wordings of questions, identifying ambiguous ones, testing the techniques that were used in the data collection, and measuring the effectiveness of the standard invitations to respondents.

\section{Validity and Reliability}

For the purpose of ensuring validity, the researchers submitted the questionnaire to experts in the field to judge face and content validity. Their suggestions were considered. To check internal consistency, the researchers calculated the correlation between each statement and the corresponding field. The p-values (Sig.) are less than 0.05 , so the correlation coefficients of all paragraphs are significant at $\alpha=0.05$, so it can be said that all paragraphs of each field are consistent and valid to be measure what it was set for Table 5 clarifies the correlation coefficient for each field and the whole questionnaire. The p-values (Sig.) are less than 0.05 , so the correlation coefficients of all the fields are significant at $\alpha=0.05$. Therefore, it can be said that the fields are valid to measure what they were set for to achieve the main aim of the study Table 6 shows the values of Cronbach's Alpha for each field of the questionnaire and the entire questionnaire. For the fields, values of Cronbach's Alpha were in the range from 0.697 and 0.962 . This range is considered high; the result ensures the reliability of each field of the questionnaire. Cronbach's Alpha equals 0.909 for the entire questionnaire which indicates an excellent reliability of the entire questionnaire. Thereby, it can be said that the researcher proved that the questionnaire was valid, reliable, and ready for distribution to the population sample. Table 7 shows that $70.3 \%$ of the study sample is males and $29.7 \%$ is females. Referring to Table 4, it is clear that the number of male teachers who quit their jobs is close to that of female teachers at schools which belong to most directorates. The majority of the study population, were married, representing $93.7 \%$ while $6.3 \%$ were single Table 8 shows

\begin{tabular}{|l|l|c|c|}
\hline No. & Field & $\begin{array}{c}\text { Correlation } \\
\text { Coefficient }\end{array}$ & P-Value \\
\hline 1. & Employment perception & 0.585 & $0.000^{*}$ \\
\hline 2. & Union Presence & 0.574 & $0.000^{*}$ \\
\hline 3. & Payment & 0.55 & $0.001^{*}$ \\
\hline 4. & Job Performance & 0.646 & $0.000^{*}$ \\
\hline 5. & Role Clarity & 0.719 & $0.000^{*}$ \\
\hline 6. & Overall job satisfaction & 0.652 & $0.000^{*}$ \\
\hline 7. & Organizational Commitment & 0.645 & $0.000^{*}$ \\
\hline & External and Work Related Factors & 0.944 & $0.000^{*}$ \\
\cline { 2 - 4 } & Turnover & 0.391 & $0.016^{*}$ \\
\hline
\end{tabular}

${ }^{\star}$ Correlation is significant at 0.05 level

Table 5: Correlation coefficient of each field and the whole of questionnaire.

\begin{tabular}{|l|l|l|}
\hline No & Field & Cronbach's alpha \\
\hline 1. & Employment Perception & 0.789 \\
\hline 2. & Union Presence & 0.962 \\
\hline 3. & Payment & 0.762 \\
\hline 4. & Job Performance & 0.905 \\
\hline 5. & Role Clarity & 0.875 \\
\hline 6. & Overall Job Satisfaction & 0.83 \\
\hline 7. & Organizational Commitment & 0.697 \\
\hline & External and Work Related Factors & 0.92 \\
\hline & Turnover & 0.863 \\
\hline & All items of the questionnaire & 0.909 \\
\hline
\end{tabular}

Table 6: Cronbach's Alpha for each field of the questionnaire. 


\begin{tabular}{|l|c|c|}
\hline Gender & Frequency & Percent \\
\hline Male & 168 & 70.3 \\
\hline Female & 71 & 29.7 \\
\hline Total & $\mathbf{2 3 9}$ & $\mathbf{1 0 0}$ \\
\hline
\end{tabular}

Table 7: Gender.

\begin{tabular}{|l|c|c|}
\hline Number of Children & Frequency & Percent \\
\hline None & 27 & 11.3 \\
\hline 2 or less & 68 & 28.5 \\
\hline 03-May & 111 & 46.4 \\
\hline 6 or more & 33 & 13.8 \\
\hline Total & 239 & 100 \\
\hline
\end{tabular}

Table 8: Number of Children.

\begin{tabular}{|l|c|c|}
\hline Age & Frequency & Percent \\
\hline Less than 25 & 5 & 2.1 \\
\hline 25 to less than 30 & 59 & 24.7 \\
\hline 30 to less than 35 & 94 & 39.3 \\
\hline 35 to less than 40 & 64 & 26.8 \\
\hline 40 to less than 45 & 13 & 5.4 \\
\hline 45 or more & 4 & 1.7 \\
\hline Total & 239 & 100 \\
\hline
\end{tabular}

Table 9: Age.

\begin{tabular}{|l|c|c|}
\hline Years of experience & Frequency & Percent \\
\hline Less than 5 years & 63 & 26.4 \\
\hline 5 to less than 10 & 105 & 43.9 \\
\hline 10 to less than 15 & 61 & 25.5 \\
\hline 15 to less than 20 & 6 & 2.5 \\
\hline 20 to less than 25 & 4 & 1.7 \\
\hline 25 or more & - & - \\
\hline Total & 239 & 100 \\
\hline
\end{tabular}

Table 10: Years of experience at your last job.

that $11.3 \%$ of the sample does not have any children, $28.5 \%$ has 2 or less, $46.4 \%$ has 3 to 5 children, and $13.8 \%$ has 6 or more Table 9 shows that the age of $2.1 \%$ of the sample is less than 25 years, $24.7 \%$ ranges between 25 to less than 30 years, $39.3 \%$ ranges between 30 to less than 35 years, $26.8 \%$ ranges between 35 to less than 40 years, that's mean $90.8 \%$ ranges between 25 to less than 40 years, $5.4 \%$ ranges between 40 to less than 45 years and $1.7 \%$ is 45 years or more. Table 10 shows that $26.4 \%$ of the sample members have less than 5 years of experience, $43.9 \%$ have 5 to less than 10 years of experience, $25.5 \% 10$ to less than 15 years of experience, $2.5 \%$ have 15 to less than 20 years of experience and $1.7 \%$ have 20 to less than 25 years of experience. Table 11 shows the mean of all items equals $5.11(51.1 \%)$, Test-value $=-18.13$ and $\mathrm{P}$-value $=0.000$ which is smaller than the level of significance $(\alpha=0.05)$. The mean of all items is significantly different from the hypothesized value 3. We conclude that the respondents disagreed on all items of external and work related factors. From the table, the researcher concludes that the respondents do not agree on the salary factor (i.e., it comes last). To explain the responses of the respondents, the researcher notices their dissatisfaction with the salaries. It appears that to them, the salaries they receive are less than those received by employees who fill similar alternative positions; or that the salaries do not cover their expenses. In the list of items disagreed on by the respondents, job satisfaction follows salaries. It seems to the researcher that the sample's responses tend to show dissatisfaction with the work conditions and that they do not feel psychologically comfortable there. Organizational Commitment comes third in line; which means respondents link quitting their jobs to the weak organizational commitment, emotional correlation and affiliation they have towards the institution. As for the

\begin{tabular}{|l|c|c|c|c|c|c|c|}
\hline Item & Mean & S.D & $\%$ & Test value & P-value & Rank \\
\hline Employment perception & 7.21 & 1.12 & 72.1 & 16.67 & $0.000^{*}$ & 2 \\
\hline Union Presence & 4.43 & 1.87 & 44.3 & -12.95 & $0.000^{*}$ & 4 \\
\hline Payment & 1.68 & 0.64 & 16.8 & -103.93 & $0.000^{*}$ & 7 \\
\hline Job Performance & 8.53 & 1.02 & 85.3 & 38.24 & $0.000^{*}$ & 1 \\
\hline Role Clarity & 6.7 & 2.04 & 67 & 5.29 & $0.000^{*}$ & 3 \\
\hline Overall Job Satisfaction & 2.62 & 0.98 & 26.2 & -53.5 & $0.000^{*}$ & 6 \\
\hline Organizational Commitment & 4.3 & 2.12 & 43 & -12.43 & $0.000^{*}$ & 5 \\
\hline External and Work Related Factors & 5.11 & 0.76 & 51.1 & -18.13 & $0.000^{*}$ & \\
\hline *The mean is significantly different from 6 & & & & \\
\hline
\end{tabular}

Table 11: Means and Test values for all item of Model Factors.

respondents' strong agreement, the researcher notices that the sample agrees on Job Performance. It appears that they were satisfied with their level of performance were keen to achieve the general objectives of the organization. As for the availability of alternative work, the researcher believes that the respondents' responses indicate that the availability of alternative work plays a role in motivating employees to move from work in the Ministry of Education's institutions to other workplaces. As for Role Clarity and the Presence of a Union, the researcher concludes that the respondents' agreement on Role Clarity comes third in line, and is followed by the Presence of a Union (fourth in line). The Test Value, though, shows their disagreement on the statements of this section which measures the employees' degree of satisfaction with the union's activities and measures how effective the union is in meeting the demands of the employees.

\section{Research Hypothesis}

There is a significant statistical correlation at $(\alpha=0.05)$ level between the external and work related factors and employees' turnover phenomenon at the Ministry of High Education in Gaza. Table 12 shows that the correlation coefficient between external and work related Factors and the employees' turnover phenomenon at the Ministry of High Education in Gaza=-.379 and the p-value (Sig.) $=0.000$. The p-value (Sig.) is less than 0.05 , so the correlation coefficient is statistically significant at $\alpha=0.05$. We conclude that there exists a significant relationship between external and work related factors and the employees' turnover phenomenon at the Ministry of High Education in Gaza. These results were consistent with. While in humanitarian organizations Employment Perception is a significant variable that affects Turnover, Union Presence is not. Work-related factors (payment, job performance, role clarity, job satisfaction and organizational commitment) are significant variables that affect Turnover and do play an important role at humanitarian organizations. There is a statistically significant effect of the external and work related factors at $(\alpha=0.05)$ level on the employees' turnover phenomenon at the Ministry of High Education in Gaza. The Multiple Linear Regression Model is used and the following results are obtained: Table 13 shows the flowing results:

- The Multiple Correlation Coefficient $\mathrm{R}=0.776$ and $\mathrm{R}$-Square $=0.589$. This means that $58.9 \%$ of the variation in Turnover is explained by all independent variables together "Employment Perception, Union Presence, Payment, Job Performance, Role Clarity, Overall Job Satisfaction and Organizational Commitment".

- The analysis of Variance for the regression model. $\mathrm{F}=49.816$, Sig. $=0.000$, so there is a significant relationship between the dependent variable "Turnover" and the independent variables "Employment Perception, Union Presence, Payment, Job Performance, Role Clarity, Overall Job Satisfaction and Organizational Commitment". 


\begin{tabular}{|c|c|c|}
\hline & Correlation Coefficient & P-Value \\
\hline Relationship between Employment perception and the phenomenon of employees' turnover & 0.369 & $0.000^{*}$ \\
\hline Relationship between Union Presence and the phenomenon of employees' turnover & -0.035 & 0.297 \\
\hline Relationship between Payment Factors and the phenomenon of employees' turnover & -0.55 & $0.000^{*}$ \\
\hline Relationship between Job Performance and the phenomenon of employees' turnover & 0.327 & $0.000^{*}$ \\
\hline Relationship between Role Clarity and the phenomenon of employees' turnover & -0.328 & $0.000^{*}$ \\
\hline Relationship between Overall job satisfaction and the phenomenon of employees' turnover & -0.628 & $0.000^{*}$ \\
\hline Relationship between Organizational Commitment and the phenomenon of employees' turnover & -0.513 & $0.000^{*}$ \\
\hline Relationship between External and Work Related Factors and the phenomenon of employees' turnover & -0.379 & $0.000^{*}$ \\
\hline${ }^{*}$ Correlation is significant at 0.05 level. & & \\
\hline
\end{tabular}

Table 12: Correlation coefficient between external and work related factors and employees' turnover phenomenon.

\begin{tabular}{|c|c|c|c|c|c|c|c|}
\hline Variable & B & $\mathbf{T}$ & Sig. & $\mathbf{R}$ & R-Square & $\mathbf{F}$ & Sig. \\
\hline (Constant) & 6.677 & 13.925 & $0.000^{*}$ & & & & \\
\hline Employment Perception & 0.215 & 5.161 & $0.000^{*}$ & \multirow{7}{*}{0.776} & \multirow{7}{*}{0.589} & \multirow{7}{*}{49.816} & \multirow{7}{*}{$0.000^{* *}$} \\
\hline Union Presence & 0.022 & 0.899 & 0.369 & & & & \\
\hline Payment & -0.269 & -2.721 & $0.007^{*}$ & & & & \\
\hline Job Performance & 0.249 & 5.45 & $0.000^{*}$ & & & & \\
\hline Role Clarity & -0.044 & -1.719 & $0.044^{*}$ & & & & \\
\hline Overall Job Satisfaction & -0.37 & -5.612 & $0.000^{*}$ & & & & \\
\hline Organizational Commitment & -0.103 & -3.867 & $0.000^{*}$ & & & & \\
\hline
\end{tabular}

Table 13: Results of Multiple Linear Regression Analysis.

\section{- The estimated regression equation is}

Turnover $=6.677+0.215 \times$ employment perception $+0.022 \times$ union presence- $0.269 \times$ payment $+0.249 \times$ job performance $-0.044 \times$ role clarity $-0.370 \times$ job satisfaction $-0.103 \times$ organizational commitment.

The estimated regression equation is used to predict the value of Turnover for any give values (responses) to the independent variables. For the variable "Employment Perception", the t-test $=5.161$, the $\mathrm{P}$-value (Sig.) $=0.000$, which is smaller than 0.05 , hence this variable is statistically significant. Since the indication of the test is positive, then there is a significant positive effect of the variable "Employment Perception" on Turnover. This result is consistent with the results of Dubey et al. in which the researchers have argued that the humanitarian workers' decision to leave their organizations is guided by the attractiveness of the job [13]. This study found that the "employment perception" is a significant variable that affects Turnover. Bee et al. study showed that there is a moderate relationship between the independent variable "perceived alternative employment opportunities" and the dependent variable "job turnover intention" [43]. Another study in Singapore, Chew et al. revealed that professionals, managers, executives and technicians are found to be heavily swayed by better external opportunities [40]. Regarding the variable "Union Presence", the $\mathrm{t}$-test $=0.899$, the $\mathrm{P}$-value (Sig.) $=0.369$, which is greater than 0.05 ; hence this variable is statistically insignificant. Therefore, there is an insignificant effect of the variable "union presence" on Turnover. This result is consistent with the results of Dubey et al. who found that Union Presence is not a significant variable that affects Turnover in humanitarian organizations [13]. However, Park study found that employees in union firms have higher intention towards job turnover, so it is inconsistent with the current result. The researcher explains that there is no relationship between the unions and the Job Turnover. The research population consisted of the employees and staff who follow the union of employees, engineers or accountants; and teachers who follow the union of teachers. There may be discrepancies in the responsibilities of each union and the extent of employees' satisfaction with their achievements. Because of the fact that employees may have moved from one governmental job to another governmental job, unions remain the same and do not change. Therefore, the union does not affect employees' decision to change their workplace; there must be other reasons and considerations that make employees decide to change their jobs. As for the variable "Payment ", the t-test $=-2.721$, the $\mathrm{P}$-value (Sig.) $=0.007$, which is smaller than 0.05 ; hence this variable is statistically significant. Since the indication of the test is negative, then there is a significant negative effect of the variable payment factor on Turnover. This result is consistent with the results of Dubey et al. who found that there is a significant negative effect of the variable "payment" on Turnover; indicating that payment does play an important role in humanitarian organizations [13]. The result is also consistent with study, which revealed that money (i.e. salaries and financial rewards) affects Turnover and the resignation of doctors in Hebron and Bethlehem. Other studies like Jadayil explored 5 variables that could affect Turnover, salary being one of them in the Industrial Sector of Jordan. The main reason for Turnover among private schools' teachers in the southern region of Jordan is low salaries. The result of Assefa [15] study is also consistent with the result of this study [15]. It stated that the main reasons behind teachers' turnover in public general secondary schools of Addis Ababa were insufficient salaries and lack of privileges. Hassan study found that payment levels have a significant negative relation with Turnover [45]. In addition, the result of this study is consistent with study which found that certain variables are crucial in influencing nurses' decisions to either leave or remain in public hospitals in Jordan, a pay level was one of these variables. Chew et al. found that annual salaries influence Turnover Intentions indirectly through mediation and moderation effects on (professionals, managers, executives and technicians) PMET's satisfaction with compensation in Singapore [40]. For the variable "Job Performance", the $t$-test $=5.450$, the P-value (Sig.) $=0.000$, which is smaller than 0.05 . Hence, this variable is statistically significant. Since the indication of the test is positive, then there is a significant positive effect of the variable "job performance" on Turnover. This result is inconsistent with the results of Dubey et al. who found that there is a significant negative effect of the job performance factor on Turnover [13]. Lai and Chen [46] found 
that there was no significant positive relationship between the Job Performance and Turnover Intention. The researcher attributes the differing results of these studies to two reasons. First: When the employees' performance is high and convincing and provides outputs with high quality, it is more likely for them to receive offers from alternative institutions. Second: In the event that the employee receives a weak salary or is not satisfied with his/her job and has a high performance, the chances of his/her leaving his/her job will increase. For the variable "Role Clarity", the t-test $=-1.719$, the P-value (Sig.) $=0.044$, which is smaller than 0.05 . Therefore, this variable is statistically significant. Since the sign of the test is negative, then there is a significant negative effect of "the role clarity" factor on Turnover. This result is consistent with the results of who found that there was a significant negative effect of "the role clarity" variable on Turnover. Hassan [44] noted that offices with a high level of role clarification had significantly higher levels of work satisfaction and lower rates of Turnover [44]. For the variable "Overall Job Satisfaction", the t-test $=-5.612$, the P-value (Sig.) $=0.000$, which is smaller than 0.05 . Hence, this variable is statistically significant. Since the sign of the test is negative, then there is a significant negative effect of the overall job satisfaction on Turnover [45]. This result is consistent with several other studies that proved the presence of a significant negative effect of the variable "job satisfaction" on Turnover. Bee et al. study showed a moderate relationship between the independent variable, Job Satisfaction, and the dependent variable, Job Turnover Intention [43]. Lai and Chen [46] also concluded that Job Satisfaction had negative effects on Turnover Intentions. The latter research was chosen on the basis of convenience sampling and was selected from automobile sales persons of Taipei, Taiwan. The variable "organizational commitment" is statistically significant because the t-test value $=-3.867$ and the $P$-value (Sig.) $=0.000$, which is smaller than 0.05 . Since the sign of the test is negative, then there is a significant negative effect of this variable on Turnover. This result is consistent with the results of Dubey et al. who found that there was a significant negative effect of the variable organizational commitment on turnover [13]. The latter research even considered organizational commitment to be one of the main factors that influenced turnover intention among technical employees in information technology organization in Malaysia. Another study Bee et al. showed a moderate relationship between the independent variable "organizational commitment" and the dependent variable "job turnover intention" [43]. Park discovered that one of the fundamental consequences of organizational commitment is decreased intention to quit the organization in the United States. Jehanzeb et al. [32] also revealed that organizational commitment had a negative effect on Turnover Intentions among employees in the private sector of Saudi Arabia. In addition, based on the P-value (Sig.), the most significant independent variable is the Overall Job Satisfaction followed by Job Performance, Employment Perception, Organizational Commitment, Payment, Role Clarity and finally Presence of a Union.

There are statistically significant differences at $(\alpha=0.05)$ level among the respondents' opinions on the factors that affect employees' turnover at the Ministry of High Education in Gaza. The differences can be attributed to the characteristics factors such as gender, marital status, number of children, previous place of work, age, degree and years of experience.

This hypothesis can be divided into the following sub-hypotheses:

There are statistically significant differences at ( $\alpha=0.05$ ) level among the respondents in their opinions about the factors that affect employees' turnover at the Ministry of High Education in Gaza attributed to Gender factor.
Table 14 shows that the p-value (Sig.) is smaller than the level of significance $\alpha=0.05$ for the field "employment perception", then there is a significant difference between respondents toward this field due to Gender factor. The researcher concludes that the personal characteristic "gender" has an effect on this field.

The researcher attributes the differences toward the field "employment perception" among the respondents to "gender" because women prefer teaching jobs for the social values, less working hours and the availability of more holidays. On the other hand, institutions prefer to hire men because their lives are more stable, they do not ask for maternity leaves and they are sometimes more suitable to the nature of the profession and its pressures. In addition, published advertisements of some jobs with high administrative titles are sometimes specified for men only because they have more managerial and leadership capabilities than women.

For the other fields, the p-value (Sig.) is greater than the level of significance $(\alpha=0.05)$, which indicates that there is an insignificant difference among the respondents toward these fields due to "gender". The researcher concludes that the personal characteristic "gender" has no effect on the other fields.

The researcher justifies the fact that the differences among the respondents attributed to gender are insignificant as the other sectors affect men and women in a similar way. For instance, the presence of employees' union does not differentiate between men and women in the decisions. In addition, both genders follow the same salary scale and face the same conditions and thus their satisfaction and commitment are somewhat similar. This result is consistent with study that found that "gender" had no significant impact on Turnover. However, this result does not come in line with the results of Almakli found that there is actually a relation between the two, as $p<0.05$. Regarding Assefa [15] he found that both genders' decisions regarding quitting or not were the same.

There are statistically significant differences at $(\alpha=0.05)$ level among the respondents in their opinions on the factors affecting employees' turnover at the Ministry of High Education in Gaza attributed to the number of children.

Table 15 shows that the p-value (Sig.) is greater than the level of significance $(\alpha=0.05)$ for each field. This indicates that there are no significant differences among the respondents toward each field due to the number of children. The researcher concludes that the personal characteristic "number of children" of employees has no effect on any field. This result is inconsistent with Dubey study that found that the number of children had a significant impact on Turnover. In Almakli study, having children does not greatly affect Turnover which is

\begin{tabular}{|l|c|c|c|c|}
\hline \multirow{2}{*}{ Field } & \multicolumn{2}{|c|}{ Means } & \multirow{2}{*}{$\begin{array}{c}\text { Test } \\
\text { Value }\end{array}$} & Sig. \\
\hline Union Presence & Male & Female & . & \\
\cline { 2 - 4 } & 7.31 & 6.97 & 2.167 & $0.031^{*}$ \\
\hline Payment & 4.31 & 4.72 & -1.555 & 0.121 \\
\hline Job Performance & 1.69 & 1.67 & 0.191 & 0.849 \\
\hline Role Clarity & 8.51 & 8.56 & -0.322 & 0.747 \\
\hline Overall Job Satisfaction & 6.72 & 6.65 & 0.251 & 0.802 \\
\hline Organizational Commitment & 2.56 & 2.78 & -1.644 & 0.102 \\
\hline External and Work Related Factors & 4.13 & 4.69 & -1.871 & 0.063 \\
\hline Turnover & 5.08 & 5.19 & -1.085 & 0.279 \\
\hline All items of the questionnaire & 8.38 & 8.1 & 1.887 & 0.06 \\
\hline *The mean difference is significant at 0.05 level. & 5.81 & 5.84 & -0.372 & 0.711 \\
\hline
\end{tabular}

Table 14: Independent Samples T-test of the fields and their $p$-values for gender. 


\begin{tabular}{|c|c|c|c|c|c|c|c|}
\hline \multirow[t]{2}{*}{ No. } & \multirow[t]{2}{*}{ Field } & \multicolumn{4}{|c|}{ Means } & \multirow[t]{2}{*}{ Test Value } & \multirow[t]{2}{*}{ Sig. } \\
\hline & & None & 2 or less & 03-May & 6 or more & & \\
\hline 1 & Employment Perception & 7.09 & 7.27 & 7.18 & 7.3 & 0.244 & 0.865 \\
\hline 2 & Union Presence & 3.99 & 4.22 & 4.64 & 4.55 & 1.282 & 0.281 \\
\hline 3 & Payment & 1.78 & 1.57 & 1.75 & 1.58 & 1.653 & 0.178 \\
\hline 4 & Job Performance & 8.33 & 8.55 & 8.56 & 8.54 & 0.389 & 0.761 \\
\hline 5 & Role Clarity & 6.25 & 6.46 & 6.89 & 6.91 & 1.199 & 0.311 \\
\hline 6 & Overall Job Satisfaction & 2.64 & 2.45 & 2.77 & 2.47 & 1.919 & 0.127 \\
\hline \multirow[t]{4}{*}{7} & Organizational Commitment & 3.85 & 4.01 & 4.58 & 4.28 & 1.502 & 0.215 \\
\hline & External and Work Related Factors & 4.89 & 4.98 & 5.24 & 5.13 & 2.566 & 0.055 \\
\hline & Turnover & 8.21 & 8.49 & 8.15 & 8.47 & 1.855 & 0.138 \\
\hline & All items of the questionnaire & 5.63 & 5.75 & 5.88 & 5.87 & 2.071 & 0.105 \\
\hline
\end{tabular}

Table 15: ANOVA test of the fields and their p-values for the number of children.

\begin{tabular}{|c|c|c|c|c|c|c|c|}
\hline \multirow[t]{2}{*}{ No. } & \multirow[t]{2}{*}{ Field } & \multicolumn{4}{|c|}{ Means } & \multirow[t]{2}{*}{ Test Value } & \multirow[t]{2}{*}{ Sig. } \\
\hline & & Less than 30 & $\begin{array}{l}30 \text { to less } \\
\text { than } 35\end{array}$ & $\begin{array}{l}35 \text { to less } \\
\text { than } 40\end{array}$ & 40 or more & & \\
\hline 1 & Employment Perception & 7.13 & 7.27 & 7.16 & 7.44 & 0.474 & 0.701 \\
\hline 2 & Union Presence & 3.96 & 4.39 & 4.81 & 5.03 & 2.901 & $0.036^{*}$ \\
\hline 3 & Payment & 1.58 & 1.6 & 1.82 & 2 & 3.574 & $0.015^{*}$ \\
\hline 4 & Job Performance & 8.48 & 8.71 & 8.37 & 8.3 & 1.907 & 0.129 \\
\hline 5 & Role Clarity & 6.29 & 6.56 & 7.11 & 7.45 & 2.697 & 0.047 \\
\hline 6 & Overall Job Satisfaction & 2.49 & 2.54 & 2.77 & 3.06 & 2.233 & 0.085 \\
\hline \multirow[t]{4}{*}{7} & Organizational Commitment & 3.82 & 4.43 & 4.54 & 4.42 & 1.503 & 0.214 \\
\hline & External and Work Related Factors & 4.87 & 5.12 & 5.26 & 5.42 & 4.05 & $0.008^{*}$ \\
\hline & Turnover & 8.48 & 8.38 & 8.1 & 7.89 & 2.44 & 0.065 \\
\hline & All items of the questionnaire & 5.67 & 5.84 & 5.89 & 5.96 & 2.464 & 0.063 \\
\hline
\end{tabular}

Table 16: ANOVA test of the fields and their $p$-values for age.

\begin{tabular}{|c|c|c|c|c|c|c|}
\hline \multirow[t]{2}{*}{ No. } & \multirow[t]{2}{*}{ Field } & \multicolumn{3}{|c|}{ Means } & \multirow[t]{2}{*}{ Test Value } & \multirow[t]{2}{*}{ Sig. } \\
\hline & & $\begin{array}{c}\text { Less than } 5 \\
\text { years }\end{array}$ & $\begin{array}{c}5 \text { to less than } \\
10\end{array}$ & $\begin{array}{l}10 \text { years and } \\
\text { more }\end{array}$ & & \\
\hline 1 & Employment Perception & 7.07 & 7.22 & 7.32 & 0.436 & 0.701 \\
\hline 2 & Union Presence & 4.65 & 4.27 & 4.47 & 0.444 & $0.036^{*}$ \\
\hline 3 & Payment & 1.69 & 1.6 & 1.78 & 0.193 & $0.015^{*}$ \\
\hline 4 & Job Performance & 8.46 & 8.62 & 8.46 & 0.502 & 0.129 \\
\hline 5 & Role Clarity & 6.77 & 6.59 & 6.8 & 0.758 & 0.047 \\
\hline 6 & Overall Job Satisfaction & 2.62 & 2.56 & 2.72 & 0.579 & 0.085 \\
\hline \multirow[t]{5}{*}{7} & Organizational Commitment & 4.24 & 4.29 & 4.35 & 0.963 & 0.214 \\
\hline & External and Work Related Factors & 5.11 & 5.07 & 5.17 & 0.685 & $0.008^{*}$ \\
\hline & Turnover & 8.2 & 8.39 & 8.24 & 0.458 & 0.065 \\
\hline & All items of the questionnaire & 5.79 & 5.8 & 5.85 & 0.806 & 0.063 \\
\hline & \multicolumn{6}{|c|}{${ }^{*}$ The mean difference is significant at 0.05 level } \\
\hline
\end{tabular}

Table 17: ANOVA test of the fields and their $p$-values for years of experience.

consistent with the current study. There are statistically significant differences at $(\alpha=0.05)$ level among the respondents in their opinions about the factors that affect employees' turnover at the Ministry of High Education in Gaza attributed to age. Table 16 shows that the p-value (Sig.) is smaller than the level of significance $(\alpha=0.05)$ for the fields "Union Presence, Payment and External and Work Related Factors". This means that there is a significant difference among the respondents toward these fields due to age.

For the other fields, the p-value (Sig.) is greater than the level of significance $(\alpha=0.05)$. Thus, there is insignificant difference among the respondents toward these fields due to age. We conclude that the personal characteristic "age" has no effect on the other fields. The researcher attributes the differences among the respondents toward the two fields "Union Presence and Payment" to age because employees in the Ministry of Education are divided into two categories after the political division. The old employees, who still belong to the West Bank employees' union, receive their salaries in full and at a stable rate. Their salaries are higher than those of the Gaza employees' union, who suffer from salary delays and weak union efforts due to difficult circumstances faced by the union. For the other fields, the p-value (Sig.) is greater than the level of significance $(\alpha=0.05)$. Thus, there is insignificant difference among the respondents toward these fields due to age. We conclude that the personal characteristic "age" has no effect on the other fields. This result is consistent with Dubey who noted that age and gender had no significant impacts on Turnover. This result shows a similarity with Almalki et al. study results, which reached the conclusion that age had no true influence on Turnover Intention. however, found otherwise; older teachers showed more tendency towards staying in their jobs, unlike younger ones [35].

- There are statistically significant differences at $(\alpha=0.05)$ level among 
the respondents in their opinions about the factors that affect employees' turnover at the Ministry of High Education in Gaza attributed to years of experience.

Table 17 shows that the p-value (Sig.) is greater than the level of significance $(\alpha=0.05)$ for each field. This means that the differences among the respondents toward each field due to years of experience are insignificant. The researcher concludes that the personal characteristic "years of experience" of employee has no effect on each field. This result is inconsistent with Dubey et al. who found that the years of experience had a strong impact on Turnover [13]. The researcher attributes the differences to the fact that most of the total sample individuals left the public schools and moved to UNRWA schools where experience is not a prerequisite for employment, contrary to the functional and professional jobs where experience plays a major role and provide their employees the opportunity to move to jobs in major companies sometimes even outside the Gaza Strip.

\section{Conclusion}

a) "Employment Perception" has a statistically significant relationship with employees' turnover. This indicates that the availability of an attractive alternative job motivates the employees to leave their current job and move to an alternative one.

b) "Presence of a Union" has an insignificant relationship with employees' turnover. This means that the union is not related to and has no effects on employees' turnover at the MOHE.

c) The researcher concludes that "Payment" has a significant negative relationship with employees' turnover. This conclusion indicates that the lower the salary and the incentives are, the greater the turnover is. In other words, when the employee is dissatisfied with the salary $s \backslash$ he receives, $s \backslash$ he is more likely to leave the job at the MOHE.

d) The study shows that "Job Performance" has a significant positive relationship with employees' turnover. The researcher believes that the justification of this finding is that the employees who perform their jobs well and fulfill their duties but do not feel satisfied with their salaries or work environment and conditions naturally search for other job opportunities. Another explanation might be that good performers receive job opportunities from other institutions and companies and are easily accepted to join the staff of the organization.

e) According to the study findings, "Role Clarity" has a significant negative relationship with employees' turnover. This may be interpreted that organizations with a high level of role clarity have lower rates of Turnover.

f) The researcher concludes that "Job Satisfaction" has a significant negative relationship with employees' turnover; that is to say that job satisfaction negatively affected Turnover.

g) It is concluded that "Organizational Commitment" has a significant negative relationship with employees' turnover. The lower the employees' commitment and affiliation to the Ministry of Education is, the more likely they are to leave work and move to another job.

\section{Recommendations}

In light of the study results, the researchers suggested the following:

a) Job satisfaction has been proven as a valuable indicator of turnover intentions through the results of this study and others. Any management, then, is advised to keep job satisfaction a priority; it being more important at times of crises. b) The focus being on hard times, employees' awareness of what is going inside the organization and what its future looks like is essential. Basically, when employees feel like they are part of a family, they start feeling more connected with each other, work in harmony, and stay loyal.

c) Money, represented by payments and promotions, is a factor that greatly plays a role in the dissatisfaction of "salaried" employees. As the situation is bad, offering better payments and promotions is not an option. In fact, an organization finds itself forced to, sometimes, reduce costs, restructure the workforce, or restrict promotions. Because of how teachers feel about the higher salaries of UNRWA teachers, it is important to consider raising teachers' salaries in a way that makes them equal.

d) Another thing decision makers should take into consideration is the importance of always paying the employees on time. Delaying their additional works' dues and wages leads to their dissatisfaction. Some of those additional work duties include their assistance in the general secondary examinations, the exams of practicing the profession and the employment examinations.

e) Any organization should understand the great value of Employee Retention. High performers and talented workers should be, first, hired and retained. A preventive measure that could be applied to reduce unwanted employees' voluntary turnover or turnover intentions is to hire and attract the right employees from the beginning.

\section{Future Research}

Future research on the topic of Turnover should be directed towards the research context, the research sample, conceptual model expansion and the research approach.

More Turnover research should be carried out in developing countries. It would be beneficial to conduct the right researches, here in Palestine for instance, to measure turnovers since no formal data sources exist. Furthermore, having Turnover researched in other sectors such as the health sector or at universities would add value and understanding to the reality of turnovers. The researcher believes that future studies can benefit from including the teachers as a study sample and some factors related to the school environment as the study variables. The theoretical aspect can be further improved through the inclusion of other factors. Other popular variables that can be included are engagement, achievement, recognition, job security, retirement, social status, workload, and image. The variables could be either used as independent, moderating or mediating variables. Finally, it is recommended to conduct a study on Turnover Intentions using a qualitative approach, where the factors affecting Turnover Intentions can be identified inductively. Subsequently, the results, a conceptual model of Turnover Intentions, may be quantitatively tested. In addition to this study, an explorative study on the tangible and intangible cost of Turnover in different sectors would increase awareness about the importance of the topic of Turnover.

\section{References}

1. Morrell K, Loan-Clarke J Wilkinson AJ (2004) Organisational Change and Employee Turnover. Personnel Review 161: 173.

2. Memon MA, Salleh R, Baharom MNR, Garavan T (2016) The Link between Training Satisfaction, Work Engagement and Turnover Intention. Eur J Training Dev 40: 407-429.

3. Cao Z, Chen J, Song Y (2013) Does Total Rewards Reduce the Core Employees Turnover Intention. Int. Journal of Business and Management 8: 62 
Citation: Al-Habil WI, Allah A, Shehadah M (2017) Factors Affecting the Employees' Turnover at the Ministry of High Education in Gaza GovernoratesCase study: North and West Gaza Directorates of Education. Arts Social Sci J 8: 304. doi: 10.4172/2151-6200.1000304

4. Dess GD, Shaw JD (2001) Voluntary turnover, social capital, and organizational performance. Acad Manage Rev 26: 446-456.

5. Rahman W, Nas Z (2013) Employee Development and Turnover Intention Theory Validation. European Journal of Training and Development 564: 579.

6. Sanjeevkumar V (2012)A study on Employee's Intention to Stay in Public Companies, Kedah, Malaysia. International Journal Business Economics and Management Research 91: 101.

7. Holtom BC and Burch TC (2016) A model of turnover-based disruption in customer services. Hum Resour Manage Rev 26: 25-36.

8. Abbasi, SM, Hollman, KW (2000) Turnover: the Real Bottom Line. Public Personnel Management 29: 333-342.

9. Harter JK, Schmidt FL, Hayes TL (2002) Business-unit-level relationship between employee satisfaction, employee engagement, and business outcomes: a meta-analysis. J Appl Psychol 87: 268.

10. Moehe (2017) A Brief History of the Palestinian Ministry of Education \& Higher

11. Abdali F (2011) Impact of Employee Turnover on Sustainable Growth of Organization in Computer Graphics Sector of Karachi, Pakistan. Afro Asian J Social Sci 2: 1-27.

12. Murtaga (2017) Director of Database Department - General Personnel Council.

13. Dubey R, Gunasekaran A, Altay N, Childe SJ, Papadopoulos T, et al. (2016) Understanding employee turnover in humanitarian organizations. Ind and Commercial Training 48: 208-214.

14. Shaw JD, Delery JE, Jenkins GD, Gupta N (1998) An Organization-Leve Analysis of Voluntary and Involuntary Turnover. Academy of Management Journal 511: 525

15. Assefa T (2014) A Study on an Assessment of Teachers Turnover in Government General Secondary Schools of Addis Ababa

16. Allen DG (2008) Retaining Talent: A Guide to Analyzing and Managing Employee Turnover. SHRM Foundation Effective Practice Guidelines Series $1-43$.

17. Khan SA (2014) The factors affecting employee turnover in an organization: The case of Overseas Pakistanis foundation. African J Bus Manage 8: 25-34.

18. Tett RP, Meyer JP (1993) Job Satisfaction, Organizational Commitment, Turnover Intention, and Turnover: Path Analyses Based on Meta-Analytic Findings. Personnel Psychology 259: 293.

19. Mobley WH (1992) Employee Turnover: Causes, Consequences, and Control.

20. Bennell P (2004) Teacher Motivation and Incentives in Sub-Saharan Africa and Asia. Knowledge and Skills for Development, Brighton.

21. Stovel M, Bontis N (2002) Voluntary Turnover: Knowledge ManagementFriend or Foe? Journal of Intellectual Capital 303: 322.

22. Weiss GE, Lincoln SA (1998) Departing Employee Can Be Nightmare. Electronic News 1: 3

23. Hacker C (1996) The costs of bad hiring decisions and how to avoid them: CRC Press.

24. Coleman JS and Coleman JS (1994) Foundations of social theory: Harvard university press.

25. Chaitra MP, DTPRM (2015) A Study on Employee Turnover. To Go Go Int. Pvt Ltd. Hassan, Karnataka, India)

26. Price JL (2001) Reflections on the Determinants of Voluntary Turnover. International Journal of Manpower 600: 624
27. Swarnalatha TSP (2014) Employee Engagement and Employee Turnover.

28. Hammerberg JH (2002) Reasons given for employee turnover in a full priced department store.

29. Mesmeh AM, Al-Habil WA, Radwan AS, Aljeesh YI (2016) Why Nurses Leave their Work from Governmental Hospitals to Primary Health Care Centers in Gaza Governorates. Journal of the Islamic University for Economic and Administrative Studies, p: 24.

30. Shaheen S (2011) HR Role and Influence on the Turnover and Migration of Doctors in Hebron and Bethlehem Governorates.

31. Alhamwan M, Mat NB, Al Muala I (2015) The Impact of Organizational Factors on Nurses Turnover Intention Behavior at Public Hospitals in Jordan: How Does Leadership, Career Advancement and Pay-Level Influence The Turnover Intention Behavior Among Nurses. Journal of Management and Sustainability 5. 154 .

32. Jehanzeb K, Rasheed A, Rasheed MF (2013) Organizational commitment and turnover intentions: Impact of employee's training in private sector of Saud Arabia. Int J Bus Manage 8: 79.

33. Khasawneh AL, Lutfi A (2013) Effect of Organizational Climate on Job Turnover of Employees at Tourism Hotelsin Petra Region of Jordan. American J Social and Management Sci 4: 54-62.

34. Adeli K (2013) Job Satisfaction and its Impact on Labor Turnover (The Study of The Port Sudan Grain Silo).

35. Almalki MJ, Fitz Gerald G, Clark M (2012) The Relationship Between Quality of Work Life and Turnover Intention of Primary Health Care Nurses in Saudi Arabia. BMC Health Services Research, 12: 314.

36. Jadayil WMA (2011) Main factors causing workers turnover in Jordan industrial sector. Jordan J Mech Ind Eng 5: 161-166.

37. Alquraishi M (2010) Work Stress and its Impact on Working Turnover for the Workers in Border Guards Centers in Eastern Region (K.S.A).

38. Feky A (2009) The impact of work cycle and availability of employees on the organization performance.

39. Qatawneh MA (2007) The Turnover Factors among Private Schools Teachers in the Southern Region of Jordan

40. Chew HG, Ng KYN, Fan SW (2016) Effects of Alternative Opportunities and Compensation on Turnover Intention of Singapore PMET. International Journal of Humanities and Social Sciences 10: 701-709.

41. Aman R (2015) The Causes and Effects of Employees Turnover: The Case of Oromia Water Works Design and Supervision Enterprise AAU.

42. Pietersen C, Oni O (2014) Employee Turnover in a Local Government Department. Mediterranean Journal of Social Sciences 5: 141.

43. Bee G H, Mak I, Jak NW, Ching PZ (2014) Factors of Job Turnover Intention among Employees of Private Universities in Selangor, UTAR.

44. Hassan S (2013) The importance of role clarification in workgroups: Effects on perceived role clarity, work satisfaction and turnover rates. Public Admin Rev 73: 716-725.

45. Hassan R (2013) Factors influencing turnover intention among technical employees in information technology organization: a case of XYZ (M) SDN BHD. Inter Journal of Arts and Commerce.

46. Lai MC, Chen YC (2012) Self-Efficacy, Effort, Job Performance, Job Satisfaction, and Turnover Intention: The Effect of Personal Characteristics on Organization Performance. Int J Innovation Manage Tech 3: 387-391. 